\title{
Urban Parks and Their Accessibility in Tehran, Iran
}

\author{
Habibollah Fasihi
}

\begin{abstract}
Parks play a vital role in the well-being of communities. The spaces covered by parks and their distribution within a city should therefore observe certain standards to provide a fair access for its residents. The purpose of this research was to investigate public parks and their accessibility in Tehran, Iran. We used a comparative evaluation method for the research, in which, along with descriptive statistical methods, a buffering technique in Geographic Information System was also applied. The findings of this study revealed that the indexes of "park ratio" and "per capita" for Tehran parks are below Iran standards. High disparities in the distribution of parks have contributed to unequal access of the inhabitants of the city to these parks. While some residents live within the vicinity of 11 parks, a large part of the city, about $26 \%$ of the city's area and $18.67 \%$ of the population, is not within the access areas of any park. Creation of smaller parks in certain parts of the city should alleviate the inequality.
\end{abstract}

Keywords: urban park, accessibility, buffer technique, Tehran

\section{INTRODUCTION}

\section{Background}

$\mathbf{U}$ RBAN PARKS ARE DELINEATED open-space areas, mostly dominated by vegetation and water, and generally are reserved for public use. ${ }^{1}$ In our increasingly urbanized society, these spaces are of a strategic position in the physical environment of cities. ${ }^{2}$ As human societies are increasingly urbanized and settled in restricted spaces, park provision is of strategic significance to improve the quality of urban life in cities. ${ }^{3}$

\section{Benefits of urban parks}

Urban parks are undoubtedly one of the crucial landscapes of most cities and towns that provide numerous environmental and social functional benefits.

Dr. Habibollah Fasihi is an Assistant Professor of Geography and Urban Planning, Department of Geographical Sciences, Kharazmi University, Tehran, Iran.

${ }^{1}$ C.C. Konijnendijk, M. Annerstedt, A.B. Nielsen, and S. Maruthaveeran. "Benefits of Urban Parks: A Systematic Review," A Report for IFPRA, 2013.

${ }^{2}$ A. Chiesura. "The Role of Urban Parks for the Sustainable City," Landscape and Urban Planning 68 (2004): 129-138.

${ }^{3}$ J.R. Wolch, J. Byrne, and J.P. Newell. "Urban Green Space, Public Health, and Environmental Justice: The Challenge of Making Cities Just Green Enough," Landscape and Urban Planning 125 (2014): 234-244.
Parks are major contributors to the quality of life and health of cities' occupants and play a vital role in livability of a city. Parks and other green spaces contribute directly to the public health by reducing stress, mental disorders, ${ }^{4,5}$ and health inequalities ${ }^{6}$ and enhancing the effect of physical activity, ${ }^{7}$ perception of life quality, and self-reported general health. ${ }^{8,9}$ Indirect health benefits are conveyed by providing arenas and opportunities

\footnotetext{
${ }^{4}$ Ward C. Thompson, J. Roe, P. Aspinall, R. Mitchell, A. Clow, and D. Miller. "More Green Space is Linked to Less Stress in Deprived Communities: Evidence from Salivary Cortisol Patterns," Landscape and Urban Planning 105 (2012): 221-229.

${ }^{5}$ M. Annerstedt, P.O. Ostergren, J. Bjork, P. Grahn, E. Skarback, and P. Wahrborg. "Green Qualities in the Neighborhood and Mental Health-Results from a Longitudinal Cohort Study in Southern Sweden," BMC Public Health 12 (2012): 337.

${ }^{6}$ R. Mitchell and F. Popham. "Effect of Exposure to Natural Environment on Health Inequalities: An Observational Population Study," The Lancet 372 (2008): 1655-1660.

${ }^{7}$ R. Mitchell and F. Popham. "Effect of Exposure to Natural Environment on Health Inequalities: An Observational Population Study," The Lancet 372 (2008): 1655-1660.

${ }^{8}$ J. Maas, R.A. Verheij, P.P. Groenewegen, S. De Vries, and P. Spreeuwenberg. "Green Space, Urbanity, and Health: How Strong is the Relation?," Journal of Epidemiology and Community Health 60 (2006): 587-592.

${ }^{9}$ M. Stodolska, K.J. Shinew, J.C. Acevedo, and D. Izenstark. "Perceptions of Urban Parks as Havens and Contested Terrains by Mexican-Americans in Chicago Neighborhoods," Leisure Sciences 33 (2011): 103-126.
} 
for physical activity, ${ }^{10}$ being content of living environment and social interactions, and by different recreational activities. ${ }^{11}$ Parks, in other words, are democratic grounds that bring people from different walks of life together, fomenting a sense of community and social vitality that have been progressively lost in the last decades. ${ }^{12}$

\section{Accessibility: Definition and criteria}

Urban communities are dependent on public parks for their life longevity, mobility, and leisure, and hence, access to parks is one of the major factors affecting the health of communities. ${ }^{13}$ It is therefore critical that such resources should be considered in locations where they maximize equal access of individuals. There is evidence that distance from parks and open space is inversely associated with their use. ${ }^{14}$ Distance is often mentioned as the main environmental factor influencing the use of a green space. In cities with more parks per population, distance to parks may be a barrier to park use ${ }^{15}$ benefits from things. ${ }^{16}$ Access is typically defined according to each park's service area, represented by a circle with a radius equivalent to the maximum desired distance of users. ${ }^{17}$ This radius method, as it is referred to here, is an example of an accessibility model that determines how fast or far one must travel to reach this circle. It also indicates the spatial relationship between origin and destination, or the degree of connection of a location with others in a region, although it is often defined as "the relative nearness or proximity of one place to another.,"18 Accessibility also refers to the ease with which a site or service may be reached or obtained. ${ }^{19}$ Lau and Chiu defined accessibility as an individual's ability to take part

\footnotetext{
${ }^{10}$ E. Coombes, A.P. Jones, and M. Hillsdon. "The Relationship of Physical Activity and Overweight to Objectively Measured Green Space Accessibility and Use," Social Science and Medicine 70 (2010): 816-822.

${ }^{11}$ D. Weber and D. Anderson. "Contact With Nature: Recreation Experience Preferences in Australian Parks," Annals of Leisure Research 13 (2010): 46-69.

${ }^{12}$ L. Loures, R. Santos, and T. Panagopoulos. "Urban Parks and Sustainable City Planning-The Case of Portimão, Portugal," WSEAS Transaction on Environment and Development 10 (2007): 171-180.

${ }^{13}$ S.R. Sakip, N. Akhir, and S.O. Siti. "Determinant Factors of Successful Public Parks in Malaysia," Social and Behavioral Sciences 170 (2014): 422-432.

${ }^{14}$ A. Kaczynski and K.A. Henderson. "Environmental Correlates of Physical Activity: A Review of Evidence About Parks and Recreation," Leisure Science 29 (2007): 315-354.

${ }^{15}$ National Recreation and Parks Association. Safe routes to parks: Improving access to parks through walkability. <https:// www.nrpa.org>. (Last accessed on April 23, 2018).

${ }^{16}$ J.C. Ribot and N.L. Peluso. "A Theory of Access," Rural Sociology 68 (2009): 153-181.

${ }^{17}$ S. Nicholls. "Measuring the Accessibility and Equity of Public Parks: A Case Study Using GIS," Managing Leisure 6 (2001): 201-219.

${ }^{18} \mathrm{H}$. Yin and J. Xu. "Measuring the Accessibility of Parks: A Case Study in Shanghai," (Sixth International Conference on Fuzzy Systems and Knowledge Discovery, Shanghai, China, 2009).

${ }^{19}$ D. Gregory. Accessibility. In R.J. Johnston, D. Gregory, and D.R. Stoddart (eds). The Dictionary of Human Geography. Second Edition. (Oxford, England: Blackwell, 1986).
}

in a particular activity or set of activities. ${ }^{20}$ Accessibility to urban parks is adequate when the population is in harmony with parks' spatial distribution.

Accessibility is often challenging to quantify, and there is no single best approach for measuring this. ${ }^{21}$ The location of parks and their spatial distributions are the two central determinants in the assessment of accessibility. There have been substantial differences in how access and distance to parks and green spaces were operationalized. Stigsdotter et al. used survey respondents' self-report to indicate accessibility for a range of distances, the smallest being $300 \mathrm{~m}^{22}$ Richardson et al. used objective measurement $^{23}$ and White et al. used means within administrative units averaging $4-5 \mathrm{~km} .{ }^{24}$ Van Den Berg et al. calculated means for 1- and 3-mile buffers around individual residences ${ }^{25}$ and Annerstedt et al. calculated availability within $300 \mathrm{~m} .{ }^{26}$ Gomes considered $400 \mathrm{~m}$ as a reasonable distance for parents taking toddlers and small children to a park for daily outings and playground opportunities and a distance of $300-400 \mathrm{~m}$ is seen as a typical threshold value after which the use frequency starts to decline. ${ }^{27}$ In Europe, 300 has been proposed as a limit for people to exploit green spaces for recreational purposes and that distance is also believed to represent a person's recreational neighborhood. ${ }^{28}$ For U.S. transit planning, the typical standard for walkability is $1 / 4$ mile

${ }^{20}$ M. Unal, C. Uslu, and A. Cilek. "GIS-Based Accessibility
Analysis for Neighborhood Parks: The Case of Cukurova Dis-
trict," Journal of Digital Landscape Architecture 1 (2016): 46-56.
${ }^{21}$ J. Gutiérrez. "Location, Economic Potential and Daily
Accessibility: An Analysis of the Accessibility Impact of the
High-Speed Line Madrid-Barcelona- French Border," Journal
of Transport Geography 9 (2001): 229-242.
Kam.K. Stigsdotter, O. Ekholm, J. Schipperijn, M. Toftager, F.
Kamper-Jørgensen, and T.B. Randrup. "Health Promoting
Outdoor Environments-Associations Between Green Space,
and Health, Health-Related Quality of Life and Stress Based on
a Danish National Representative Survey," Scandinavian Journal
of Public Health 38 (2010). DOI: 10.1177/1403494810367468

${ }^{23}$ E.A. Richardson, J. Pearce, R. Mitchell, and S. Kingham. "Role of Physical Activity in the Relationship Between Urban Green Space and Health," Public Health 127 (2013). DOI: 10.1016/j.puhe.2013.01.004

${ }^{24}$ M.P. White, I. Alcock, B.W. Wheeler, and M.H. Depledge. "Would You Be Happier Living in a Greener Urban Area? A Fixed-Effects Analysis of Panel Data," Psychological Science 2013. DOI: $10.1177 / 0956797612464659$

${ }^{25}$ Van Den A.E. Berg, J. Maas, R.A. Verheij, and P.P. Groenewegen. "Green Space as a Buffer Between Stressful Life Events and Health," Social Science \& Medicine 70 (2010): $1203-1210$.

${ }^{26}$ M. Annerstedt, P.O. Östergren, J. Björk, P. Grahn, E. Skärbäck, and P. Währborg. "Green Qualities in the Neighborhood and Mental Health-Results from a Longitudinal Cohort Study in Southern Sweden," BMC Public Health 12 (2012). DOI: $10.1186 / 1471-2458-12-337$

${ }^{27}$ S.V. Gomes. The role of urban parks in cities' quality of life. European Real Estate Society 22nd Annual Conference. June 24-27, 2015. <https://eres.architexturez.net/system/files/ eres2015_183.content>

${ }^{28}$ M. Annerstedt, P.O. Östergren, J. Björk, P. Grahn, E. Skärbäck, and P. Währborg. "Green Qualities in the Neighbourhood and Mental Health-Results from a Longitudinal Cohort Study in Southern Sweden," BMC Public Health 12 (2012): 337. 
or $400 \mathrm{~m}$, and walking distance (compared with motorized travel) is a qualitative boundary to determine access. ${ }^{29}$ The "Trust for Public Land's ParkScore Index" awards each city points for access based on the percentage of the population living within a 10-minute (halfmile) walk of a public park. ${ }^{30}$ DiChiara and Koppelman categorized the parks into five categories of playgrounds, playfields, community parks, district parks, and regional parks, and considered their access areas at a distance of $0.5,0.5,1.5,2,3$, and 10 miles away from the park borders, respectively. ${ }^{31}$ According to the standards documented in various resources, Sarhan et al. divided parks into 10 categories and considered the radius of access from 1.4 miles for pocket and miniparks to 1000 5000 miles for conservancy parks. ${ }^{32}$ In I.R. Iran, researchers use the criteria set by Habibi and approved by "Iranian Ministry of Housing and Urbanism," to determine parks' access areas. Habibi and Masaeli ${ }^{33}$ divided Iranian urban parks into four categories as follows: neighboring parks with an area of less than $5000 \mathrm{~m}^{2}$ and an access area of 220-250 $\mathrm{m}$ from the park borders, local parks with an area of $4000-5000 \mathrm{~m}^{2}$ and an access area with a radius of $300-375 \mathrm{~m}$ from the park borders, regional parks with an area of $4000-8000 \mathrm{~m}^{2}$ and a radius of $650-750 \mathrm{~m}$ from the park borders, and finally, district parks with an area of more than $8000 \mathrm{~m}^{2}$ and an access area of more than $750 \mathrm{~m}$ from the park borders.

The concept of accessibility, referred to in this article, includes both walkability and park capacity. The areas of parks in Iranian cities, including those of the capital Tehran, have varied widely. Therefore, for larger parks, accessibility is determined by longer distance that must be walkable too.

While many researchers measured proximate value (nearby-ness) of parks up to $600 \mathrm{~m}$ from a large park, it should be noted that most of the value is within the first $150 \mathrm{~m} .{ }^{34}$ Many research findings have indicated that park proximity is essential for a public park usage. ${ }^{35}$ For example, people who reside within half a mile of a park,

\footnotetext{
${ }^{29}$ R. Sturm and D. Cohen. "Proximity to Urban Parks and Mental Health," The Journal of Mental Health, Policy and Economics 17 (2014): 19.

${ }^{30}$ The Trust for Public Land ParkScore ${ }^{\circledR}$. <www.parkscore.tpl .org/methodology.php>

${ }^{31}$ Di J. Chiara and L. Koppelman. Urban Planning and Design Criteria. (New York: Van Nostrand Reinhold Co., Inc., 1982).

${ }^{32}$ A. Sarhan, Y. Farghaly, and R. Elsayed. "Measures and Attributes for Sustainability of Parks," Procedia Environmental Sciences 34 (2016): 453-460.

${ }^{33}$ S.M. Habibi and S. Masaeli. Leading Urban Utility. (Iranian Ministry of Housing and Urbanism, 1999). [In Persian.]

${ }^{34}$ S.V. Gomes and T. Florentino. "The Role of Urban Parks in Cities' Quality of Life," (European Real Estate Society 22nd Annual Conference, June 24-27, 2015).

${ }^{35}$ A.T. Kaczynski and K.A. Henderson. "Parks and Recreation Settings and Active Living: A Review of Associations with Physical Activity Function and Intensity," Journal of Physical Activity \& Health 5 (2008): 619-632.

${ }^{36}$ D.A. Cohen, T.L. McKenzie, A. Sehgal, S. Williamson, D. Golinelli, and N. Lurie. "Contribution of Public Parks to Physical Activity," American Journal of Public Health 97 (2007): 509-514.
}

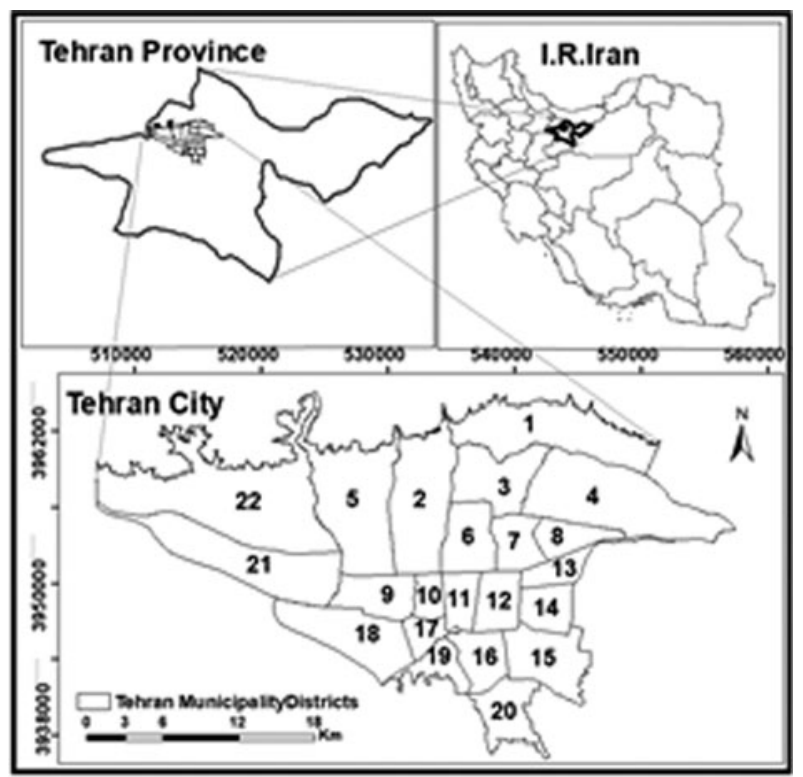

FIG. 1. Location of the studied area.

exercise five or more times a week than those who reside farther away from the park. ${ }^{36}$ It has been reported that when the distance from a park doubles, the likelihood of park usage decreases by almost $50 \% .{ }^{37}$ This research hence is to assess parks' distribution and accessibility in the city of Tehran and whether the park locations provide equal access for the city's residents.

\section{METHODS}

In this article, along with using indicators such as park ratios and per capita park areas, we conceptualized access from a spatial quantitative point of view, including the opportunity to enjoy settings that are in a certain radius of the park. Geographic Information System (GIS) provides an important spatial technique to analyze accessibility. ${ }^{38}$ We have used the Euclidean buffer method in GIS for calculating indexes of distance from the nearest park and the overlapping density of the park access area. The access area of each park was determined by a buffer around the park, its radius determined according to the criteria set by Habibi and approved by "Iranian Ministry of Housing and Urbanism." Accordingly, we consider the radius of park access areas for the parks with areas of less than $5000 \mathrm{~m}^{2}$ and more than $8000 \mathrm{~m}^{2}, 220 \mathrm{~m}$ and $800 \mathrm{~m}$ from the park

\footnotetext{
${ }^{37}$ National Recreation and Park Association. Americans broad-based support for local Recreation and Park Services: results from a nationwide study. <https://www.nrpa.org/ uploadedFiles/nrpa.org/Publications_and_Research/Research/ Park-Perception-Study-NRPA-summary.pdf>. 2016.

${ }^{38}$ K. Gupta, A. Roy, K. Luthra, S. Maithani, and D. Mahavir. "GIS Based Analysis for Assessing the Accessibility at Hierarchical Levels of Urban Green Spaces," Urban for Urban Green 18 (2016): 198-211.
} 
FIG. 2. Location of urban parks in Tehran city.

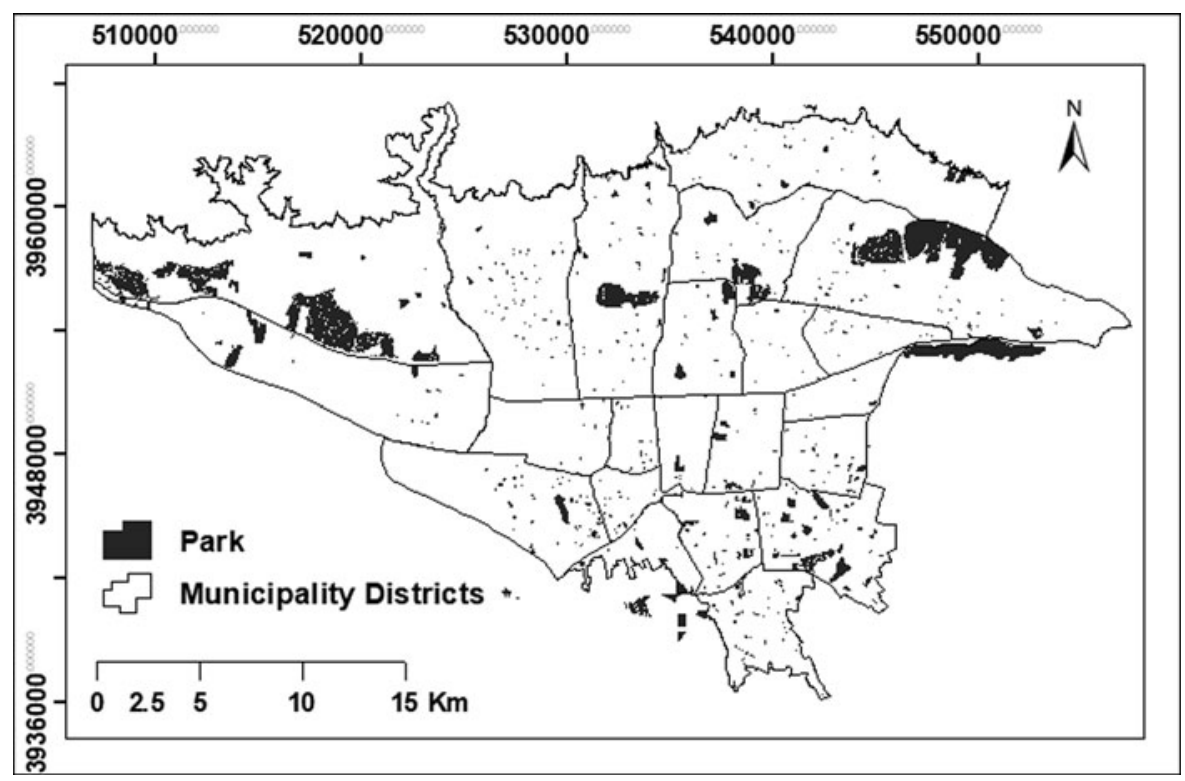

border, respectively. Considering $3000 \mathrm{~m}^{2}$ difference in areas and $580 \mathrm{~m}$ difference in the radiuses of the two categories of parks, the radius of access areas $\left(r_{i}\right)$ for any park with an area between 3000 and $8000 \mathrm{~m}^{2}$ can be calculated as follows:

$$
r_{i}=220+\left(S_{i}-3000\right) \times 0.1933,
$$

where $S_{i}$, the area of park $i$.

The data used in the article, including those of the 2016 Iranian population census and 2016 land use parcel levels, were updated through direct observations and geometries.

\section{STUDY AREA}

The study area was Tehran city. The city has an area of 66,277 ha and a population of 8.7 million. ${ }^{39}$ Tehran is the largest city and the capital of Iran. It is located in alluvial fans of the southern Alborz foothills and its average annual precipitation is about $230 \mathrm{~mm}$. The city is divided into 22 municipality districts (Fig. 1).

The location and climate of Tehran have been the reasons behind this city being selected as the capital of Iran since 1785. In many travel logs that were written one to four centuries ago, the city has been praised for its ample orchards and trees. ${ }^{40}$ However, in the last few decades, massive increase in population and physical

\footnotetext{
${ }^{39}$ Iranian Statistical Center. Selected Findings of the 2016 Public Population and Housing Census. <https://www.amar.org.ir>

${ }^{40} \mathrm{M}$. Sheibani and N. Zivdar. "Study of the Changes in Tehran Gardens in Relation to the City," (The Fourth International Conference on Planning and Environment, May 23-24, 2017, Tehran, Iran). [In Persian.]
}

growth have led to expansion of the city into orchards and agricultural lands with impacts on green spaces by the 1970s. Tehran had 75 parks, which in conjunction with forestry on the outskirt of the city, the green space was totaling 2937 ha. However, in the last few decades until 1985, despite the construction of more than 60 parks, green space per square meter is only $0.5 \mathrm{~m}^{2}$ due to expansion of the city. Construction of 1730 parks by 2012 increased green space within the city and its close periphery to 40,000 ha. More recently, with the construction of an additional 200 parks, the per capita green space has reached $25 \mathrm{~m}^{2}$. However, despite the new parks, still less than $10 \%$ of the city's area is covered by green spaces. ${ }^{41}$

\section{FINDINGS}

\section{Park ratio and per capita urban parks}

The land use map and information provided by the "Organization of Parks \& Green Spaces of Tehran Municipality," show that Tehran at present has 909 urban parks covering 5035 ha, $7.6 \%$ of the city's area (Table 2 and Fig. 2).

As shown in Table $1^{42}$, district 4 , located in northeastern Tehran, has the highest share of parks than any other district, as $16.8 \%$ of its area is covered by urban parks. Here, Levizan Park alone covers $13.2 \%$ of the area, and Tello Park has a surface area of 1000 ha. $^{43}$ In

\footnotetext{
${ }^{41}$ Organization of Parks and Green Space of Tehran Municipality. Statistics Provided by the Organization to the Author. 2017. [In Persian.]

${ }^{42}$ Municipality of Tehran. Tehran Metropolitan Atlas. 2017. $<$ www.tehran.ir >. [In Persian.]

${ }^{43}$ District 4 of Tehran Municipality. <http://region4.tehran.ir/ 2018>. [In Persian.]
} 
Table 1. Park Ratio and Per Capita in Districts of Tehran Municipality

\begin{tabular}{|c|c|c|c|c|c|}
\hline $\begin{array}{l}\text { Tehran } \\
\text { districts }\end{array}$ & Area (ha) & $\begin{array}{l}\text { Urban park } \\
\text { areas (ha) }\end{array}$ & Population & $\begin{array}{c}\text { Ratio } \\
\text { park (\%) }\end{array}$ & $\begin{array}{c}\text { Per capita } \\
\text { urban parks }\left(m^{2}\right)\end{array}$ \\
\hline 1 & 5267.5 & 138.8 & 493,889 & 2.63 & 2.81 \\
\hline 2 & 495.6 & 322.0 & 692,579 & 6.50 & 4.65 \\
\hline 2 & 2937.7 & 221.0 & 330,004 & 7.52 & 6.70 \\
\hline 4 & 6682.0 & 1122.0 & 917,261 & 16.79 & 12.23 \\
\hline 5 & 5908.1 & 66.7 & 856,565 & 1.13 & 0.78 \\
\hline 6 & 2143.5 & 112.0 & 250,753 & 5.23 & 4.47 \\
\hline 7 & 1536.5 & 11.8 & 312,002 & 0.77 & 0.38 \\
\hline 8 & 1322.3 & 16.8 & 425,044 & 1.27 & 0.40 \\
\hline 9 & 1951.6 & 12.5 & 174,115 & 0.64 & 0.72 \\
\hline 10 & 807.2 & 20.0 & 326,885 & 2.48 & 0.61 \\
\hline 11 & 1186.0 & 32.5 & 308,176 & 2.74 & 1.05 \\
\hline 12 & 1600.8 & 66.4 & 240,909 & 4.15 & 2.76 \\
\hline 13 & 1146.5 & 11.1 & 253,054 & 0.97 & 0.44 \\
\hline 14 & 1453.6 & 50.2 & 489,101 & 3.46 & 1.03 \\
\hline 15 & 2845.3 & 310.6 & 659,468 & 10.92 & 4.71 \\
\hline 16 & 1645.2 & 124.4 & 267,678 & 7.56 & 4.65 \\
\hline 17 & 826.3 & 21.8 & 278,354 & 2.64 & 0.78 \\
\hline 18 & 366.8 & 113.9 & 419,249 & 3.11 & 2.72 \\
\hline 19 & 1149.3 & 65.0 & 255,533 & 5.65 & 2.54 \\
\hline 20 & 2041.6 & 83.2 & 367,600 & 4.08 & 2.26 \\
\hline 21 & 5197.5 & 159.8 & 186,319 & 3.07 & 8.58 \\
\hline 22 & 10003.9 & 1388.4 & 175,398 & 13.88 & 79.16 \\
\hline Tehran city & 66276.9 & 5035.8 & $8,679,936$ & 7.6 & 5.80 \\
\hline
\end{tabular}

district 22, located in the northwest of Tehran, nearly $14 \%$ of lands are covered by urban parks. Chitgar $(950$ ha), Latmal (100 ha), and Rabbit (67 ha) are the three major parks in this district. ${ }^{44}$ Likewise, in district 15 , just over $10 \%$ of the land is covered by parks. In contrast, in districts 9,7 , and 13 , urban parks cover less than $1 \%$ of their lands. District 9 although had benefited from a substantial number of orchards and agricultural land, most of the lands were later allocated to the construction of airports and numerous industries. Districts 7 and 13, being the hub of Tehran since their establishment, also suffer from a low park ratio as most of their land and orchards are allocated to residential and administrative use. In general, in six districts of $2-4,15-16$, and 22 the index of "park ratio" is higher than Tehran's average $(7.6 \%)$ and is lower in other 16 districts.

The average of per capita urban parks in Tehran is $5.8 \mathrm{~m}^{2}$. In district 22 , this share is 79.2 , which is 13.6 times higher than this average. Nonresidential land usage such as Chitgar Park, Azadi Stadium with an area of 460 ha, as well as industrial towns and freeways have contributed to the lower population density of this area and hence the high share of urban parks. In this indicator, 4 districts of $3,4,21$, and 22 benefit from a higher than Tehran average in contrast to the other 18 districts. In 7 districts, the index is less than $1 \mathrm{~m}^{2}$ and in 11 districts it is $1-5 \mathrm{~m}^{2}$.

\footnotetext{
${ }^{44}$ District 22 of Tehran municipality. <http://region22.tehran .ir/2018>. [In Persian.]
}

\section{Park accessibility}

The indicators outlined above can only provide an overall situation of an area in terms of having spaces as a park, but geographical distribution of the parks and their accessibility are varied in any part of these areas. So we have applied buffer tools in GIS to analyze urban park accessibility, and the proportion of the population that resides at certain distances from the nearest park was calculated using this tool (Table 2).

Table 2. Distance Between Residential Blocks AND The Nearest Park

\begin{tabular}{lc}
\hline $\begin{array}{l}\text { Distance from } \\
\text { the nearest park }(m)\end{array}$ & $\begin{array}{c}\text { Proportion of the } \\
\text { resident population }(\%)\end{array}$ \\
\hline 100 & 33.27 \\
200 & 41.88 \\
300 & 52.04 \\
400 & 62.03 \\
500 & 71.89 \\
600 & 80.17 \\
700 & 86.61 \\
800 & 91.14 \\
900 & 94.05 \\
1000 & 95.81 \\
1100 & 97.27 \\
1200 & 98.40 \\
1300 & 98.98 \\
1400 & 99.29 \\
1500 & 99.40 \\
\hline
\end{tabular}


FIG. 3. Distance from nearest park.

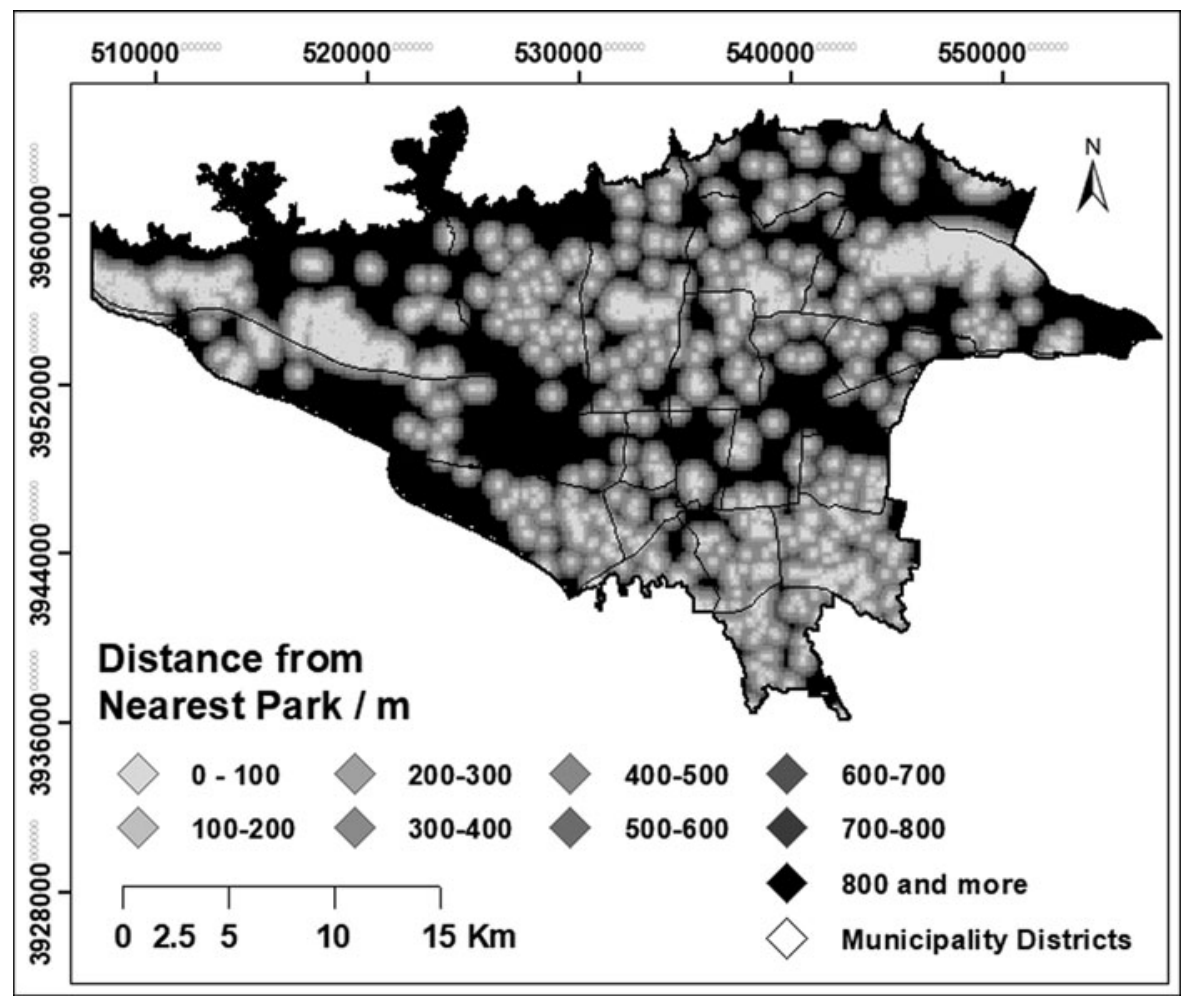

A third of Tehran population resides at a distance of less than $100 \mathrm{~m}$ from the nearest park and for slightly over half of the population this distance is less than $300 \mathrm{~m}$. Also, about $90 \%$ of the population resides at a distance of less than $800 \mathrm{~m}$ from the nearest park (Fig. 3).

The access area of each park was estimated through drawing buffers in GIS according to the abovementioned criteria (Table 3 and Fig. 4).

Approximately $26.22 \%$ of the city's area, where $1,061,020$ people are residing, is outside the parks'

Table 3. Coverage and Overlapping of PARKS' ACCESS AREAS

\begin{tabular}{lcc}
\hline $\begin{array}{l}\text { No. of } \\
\text { overlapped park } \\
\text { access areas }\end{array}$ & $\begin{array}{c}\text { Proportion } \\
\text { of Tehran } \\
\text { area }(\%)\end{array}$ & $\begin{array}{c}\text { Proportion } \\
\text { of Tehran } \\
\text { population (\%) }\end{array}$ \\
\hline 0 & 26.22 & 12.20 \\
1 & 27.68 & 24.98 \\
2 & 20.68 & 23.47 \\
3 & 11.44 & 16.35 \\
4 & 6.58 & 10.40 \\
5 & 3.76 & 6.61 \\
6 & 1.96 & 3.604 \\
7 & 1.07 & 1.704 \\
8 & 0.46 & 0.541 \\
9 & 0.13 & 0.083 \\
10 & 0.02 & 0.042 \\
11 & 0.001 & 0.009 \\
\hline
\end{tabular}

access areas (Table 3). Also, nearly 1/3 of the city's area, accommodating $1 / 5$ of the population (about 1.66 million), lies inside the access area of only one park, while 0.69 ha of the city's area and its population of 320 people are within 11 parks' access areas. More than half of the city's area (59.8\%), housing about half of the population $(52.74 \%)$, is inside the access area of 1 to 3 parks.

The most overlapping park access areas, 11 parks, belong to districts 4 and 16 . In districts 5-8, 10, 15, 17,18 , and 20 , a maximum of 10 park access area is overlapped, while in 4 districts of $1,9,21$, and 22 , the maximum overlapping of parks' access areas is only 5 . In district 14, this is 9 . In districts 12 and 3, there are a maximum of 8 overlaps of access areas of parks. In districts $7,11,13$, and 18 , it is 7 , and finally, in district 2 , there are 6 overlaps of access areas of parks.

Southern and southeastern parts of Tehran benefit from a large number of small parks improving the overlapping density of the access areas of the parks (Fig. 3). On the contrary, in the west and northwest of the city, although the proportion of the land covered by the parks is higher, the significantly larger parks have reduced the coverage and overlap (Table 4).

While in district 7, nearly half of the inhabitants and in districts 22,1 , and 11 , about $1 / 3$ of them do not reside in any park access area, in districts 16, 18, 20, and 15 , more than $95 \%$ of residences live in at least 1 park access area. 


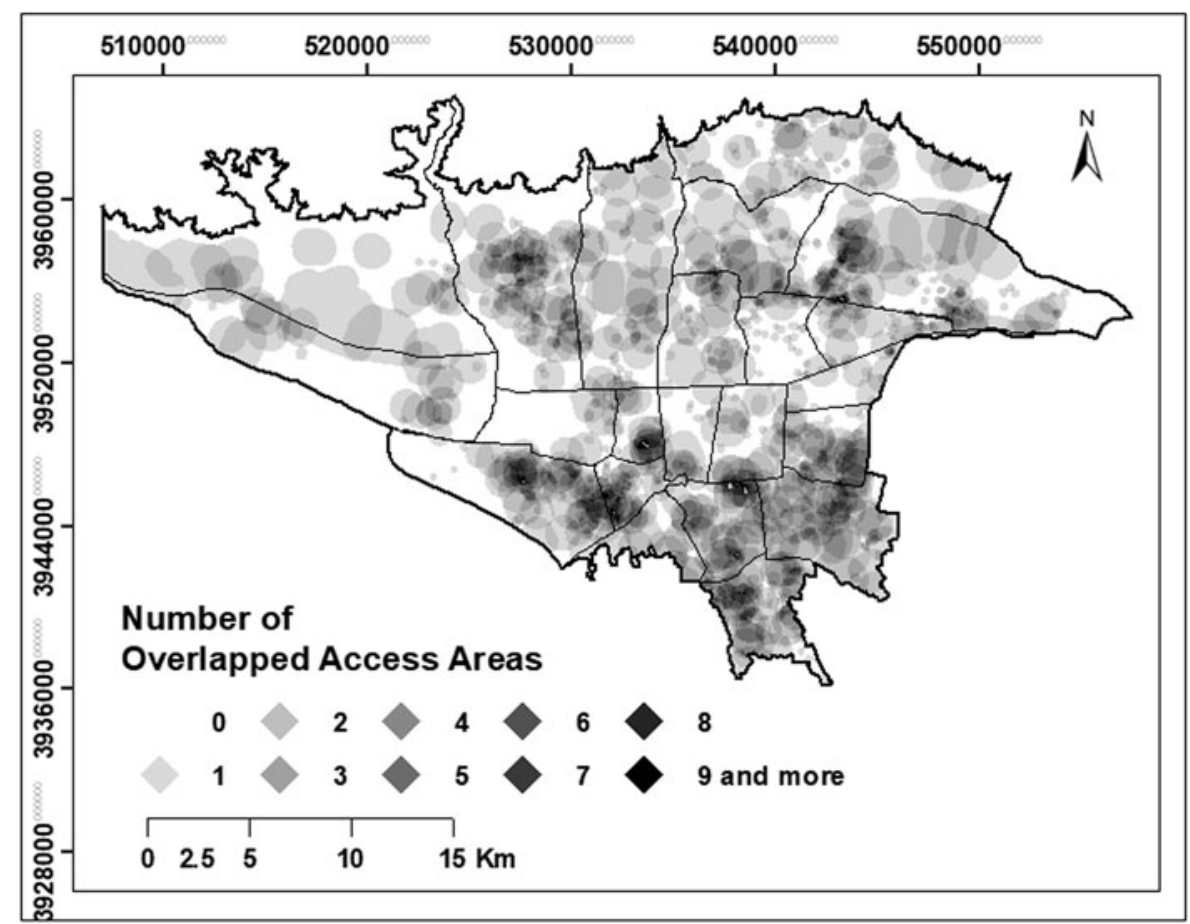

FIG. 4. Access areas of parks and their overlaps.

Table 4. Percentage of Inhabitants in 22 Districts of Tehran Municipality in Relation to Overlapped Park Access Area in These Districts

\begin{tabular}{|c|c|c|c|c|c|c|c|c|c|c|c|c|}
\hline \multirow[b]{2}{*}{ Districts } & \multicolumn{12}{|c|}{ No. of park access area overlaps } \\
\hline & 0 & 1 & 2 & 3 & 4 & 5 & 6 & 7 & 8 & 9 & 10 & 11 \\
\hline 1 & 29.13 & 32.62 & 28.68 & 8.41 & 1.09 & 0.07 & & & & & & \\
\hline 2 & 10.2 & 34.32 & 38.21 & 12.89 & 3.56 & 0.8 & 0.03 & & & & & \\
\hline 3 & 13.55 & 35.49 & 23.99 & 12.71 & 10.67 & 2.75 & 0.47 & 0.34 & 0.02 & & & \\
\hline 4 & 25.66 & 25.14 & 22.83 & 12.92 & 5.85 & 3.67 & 2.19 & 1.2 & 0.38 & 0.13 & 0.02 & 0.01 \\
\hline 5 & 37.15 & 21.19 & 15.84 & 9.62 & 7.83 & 5.43 & 1.85 & 0.65 & 0.38 & 0.06 & & \\
\hline 6 & 9.23 & 34.67 & 33.14 & 13.61 & 5.95 & 1.78 & 0.97 & 0.45 & 0.24 & & & \\
\hline 7 & 40.0 & 36.78 & 12.12 & 6.04 & 2.82 & 1.3 & 0.84 & 0.12 & & & & \\
\hline 8 & 9.32 & 39.91 & 28.46 & 15.59 & 6.12 & 2.21 & 0.45 & 0.47 & 0.37 & 0.08 & 0.02 & \\
\hline 9 & 56.38 & 23.67 & 11.08 & 7.92 & 1.74 & 0.21 & & & & & & \\
\hline 10 & 13.92 & 23.63 & 14.48 & 14.84 & 6.98 & 6.77 & 6.32 & 6.93 & 3.58 & 2.18 & 0.37 & \\
\hline 11 & 28.88 & 38.66 & 11.98 & 7.87 & 6.63 & 5.28 & 0.67 & & & & & \\
\hline 12 & 13.09 & 32.01 & 27.54 & 15.68 & 5.46 & 2.37 & 2.35 & 1.32 & 0.2 & & & \\
\hline 13 & 25.11 & 45.06 & 18.79 & 9.24 & 0.85 & 0.54 & 0.21 & & & & & \\
\hline 14 & 10.64 & 13.81 & 13.84 & 16.33 & 16.96 & 12.74 & 11.09 & 4.26 & 0.28 & 0.05 & & \\
\hline 15 & 2.14 & 6.69 & 17.72 & 28.42 & 24.48 & 12.37 & 5.48 & 2.17 & 0.46 & 0.05 & 0.01 & \\
\hline 16 & 0.89 & 8.45 & 14.97 & 21.25 & 19.68 & 18.9 & 7.49 & 3.82 & 2.89 & 1.2 & 0.44 & 0.02 \\
\hline 17 & 4.23 & 14.17 & 16.07 & 17.67 & 12.5 & 12.47 & 9.9 & 5.72 & 5.12 & 2.01 & 0.14 & \\
\hline 18 & 30.47 & 16.15 & 15.38 & 9.65 & 8.82 & 7.44 & 5.07 & 4.47 & 2.22 & 0.31 & 0.02 & \\
\hline 19 & 6.58 & 22.67 & 30.84 & 24.24 & 11.4 & 3.81 & 0.43 & 0.02 & & & & \\
\hline 20 & 4.3 & 12.9 & 17.6 & 21.1 & 17.2 & 12.8 & 8.6 & 4.1 & 1.4 & 0.1 & & \\
\hline 21 & 42.05 & 26.86 & 19.06 & 8.93 & 2.86 & 0.27 & & & & & & \\
\hline 22 & 43.07 & 38.77 & 13.77 & 3.21 & 1.21 & 0.06 & & & & & & \\
\hline
\end{tabular}




\section{CONCLUSIONS}

Public parks are a vital component of the urban landscape. The health and quality of life in each city depend largely on the existence and distribution of these parks to ensure equal access for the city's residents. Standard guidelines established in Iran advise per capita parks of at least $13 \mathrm{~m}^{2}$ in view of the natural, social, and cultural circumstances. ${ }^{45}$ The Iranian Organization of Land and Housing has recognized a standard of 5-10 $\mathrm{m}^{2}$ per capita ${ }^{46}$ and some researchers have proposed a $9 \mathrm{~m}^{2.47}$ Tehran park space per capita is significantly lower than any of these guideline values. The park space per capita is also substantially lower than the average for all other Iranian cities $\left(11.5 \mathrm{~m}^{2}\right)$. Per capita urban parks in five other highly populated cities, namely, Mashhad, Esfahan, Karaj, Shiraz, and Tabriz, are 4.18, 21.3, 0.87, 1.14 , and $7.56 \mathrm{~m}^{2}$ respectively. ${ }^{48}$ Tehran falls behind Esfahan and Tabriz, but surpasses other cities. Park ratios in these cities are $3.84,23.85,0.97,0.17$, and $5.64 \%$, respectively, ${ }^{49}$ with only Esfahan having a higher park ratio than Tehran.

High disparities in the distribution of parks in Tehran have also caused unequal access of its residents to existing parks. While a small percentage of the population resides in access areas of 11 parks, a large part of the city, which covers about $26.2 \%$ of the city's area and $18.7 \%$ of the population, is not within the access areas of any park. The substandard of parks per capita in the city of Tehran and their unequal distribution demand creation of smaller parks especially in the northwestern and southwestern regions of the city to improve quality of life for its residents.

\section{FUNDING INFORMATION}

No funding was received for this article.

Address correspondence to:
Habibollah Fasihi
Department of Geographical Sciences
Kharazmi University
No. 43 South Mofatteh Avenue
Tehran 15719-14911
Iran
E-mail: fasihi@khu.ac.ir

Address correspondence to: ographical Sciences South Mofatteh Avenue 911

E-mail: fasihi@khu.ac.ir

\footnotetext{
${ }^{45}$ Engineering Company of Jelvehsazan-e Atipaj. Standards for Park and Green Space Design. <http://landscape3design .blogfa.com>. April 24, 2018. [In Persian.]

${ }^{46}$ Iranian Organization of Land and Housing. Urban land use per capita. Ministry of Housing and Urban Planning, 1999. [In Persian.]

${ }^{47} \mathrm{E}$. Shieh. Introduction to the basics of urban planning. University of Science and Technology Publication, Tehran, 1988. [In Persian.]

${ }^{48}$ Iranian Municipality and Land Resources Organization. $<$ www.imo.org.ir/2018/8/10>. [In Persian.]

${ }^{49} \mathrm{E}$. Shieh. Introduction to the basics of urban planning. University of Science and Technology Publication, Tehran, 1988. [In Persian.]
} 